0.000.

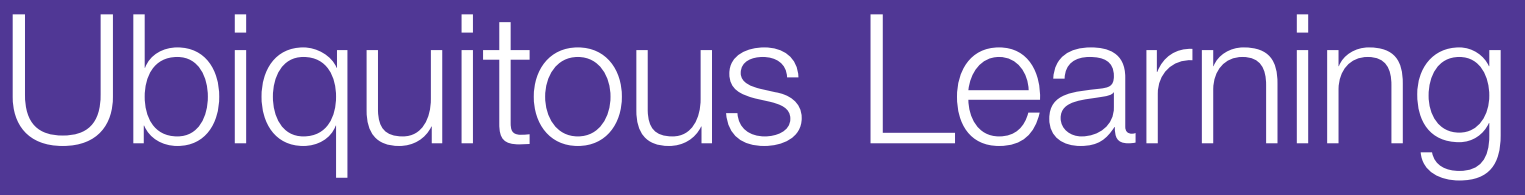

An International Journal

Science Teachers' Views and Applications of Technology-Based Teaching 


\section{EDITOR}

Bill Cope, University of Illinois at Urbana-Champaign, USA

ACTING DIRECTOR OF PUBLISHING

Jeremy Boehme, Common Ground Research Networks, USA

\section{EDITORIAL ASSISTANT}

Grace Park, Common Ground Research Networks, USA

\section{ADVISORY BOARD}

The e-Learning Research Network recognizes the contribution of many in the evolution of the Research Network. The principal role of the Advisory Board has been, and is, to drive the overall intellectual direction of the Research Network. A full list of members can be found at https://ubi-learn.com/about/advisory-board.

\section{PEER REVIEW}

Articles published in Ubiquitous Learning: An International Journal are peer reviewed using a two-way anonymous peer review model. Reviewers are active participants of the e-Learning Research Network or a thematically related Research Network. The publisher, editors, reviewers, and authors all agree upon the following standards of expected ethical behavior, which are based on the Committee on Publication Ethics (COPE) Core Practices. More information can be found at: https://ubi-learn.com/journal/model.

\section{ARTICLE SUBMISSION}

Ubiquitous Learning: An International Journal publishes quarterly (March, June, September, December). To find out more about the submission process, please visit https://ubi-learn.com/journal/call-for-papers.

\section{UBIQUITOUS LEARNING:}

\section{AN INTERNATIONAL JOURNAL}

https:/ubi-learn.com

ISSN: $1835-9795$ (Print)

ISSN: $2475-9686$ (Online)

https://doi.org/10.18848/1835-9795/CGP (Journal)

First published by Common Ground Research Networks in 2020

University of Illinois Research Park

2001 South First Street, Suite 202

Champaign, IL 61820 USA

$\mathrm{Ph}:+1-217-328-0405$

https://cgnetworks.org

Ubiquitous Learning: An International Journal

is a peer-reviewed, scholarly journal.

\section{COPYRIGHT}

(C) 2020 (individual papers), the author(s)

(C) 2020 (selection and editorial matter),

Common Ground Research Networks

All rights reserved. Apart from fair dealing for the purposes of study, research, criticism, or review, as permitted under the applicable copyright legislation, no part of this work may be reproduced by any process without written permission from the publisher. For permissions and other inquiries, please contact cgscholar.com/cg_support.

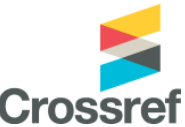

\section{ABSTRACTING AND INDEXING}

For a full list of databases in which this journal is indexed, please visit https://ubi-learn.com/journal.

\section{RESEARCH NETWORK MEMBERSHIP}

Authors in Ubiquitous Learning: An International Journal are members of the e-Learning Research Network or a thematically related Research Network. Members receive access to journal content. To find out more, visit https://ubi-learn.com/about/become-a-member.

\section{SUBSCRIPTIONS}

Ubiquitous Learning: An International Journal is available in electronic and print formats. Subscribe to gain access to content from the current year and the entire backlist.

Contact us at cgscholar.com/cg_support.

\section{ORDERING}

Single articles and issues are available from the journal bookstore at https://cgscholar.com/bookstore.

\section{HYBRID OPEN ACCESS}

Ubiquitous Learning: An International Journal is Hybrid Open Access, meaning authors can choose to make their articles open access. This allows their work to reach an even wider audience, broadening the dissemination of their research. To find out more, please visit https://ubi-learn.com/journal/hybrid-open-access.

\section{DISCLAIMER}

The authors, editors, and publisher will not accept any legal responsibility for any errors or omissions that may have been made in this publication. The publisher makes no warranty, express or implied, with respect to the material contained herein. 


\title{
Science Teachers' Views and Applications of Technology-Based Teaching
}

\author{
Oscar Koopman, Cape Peninsula University of Technology, South Africa \\ Micheal M. Van Wyk, ${ }^{1}$ University of South Africa, South Africa \\ Karen J. Koopman, University of the Western Cape, South Africa
}

\begin{abstract}
This paper investigates the following research questions: i) What are South African Further Education and Training physical science teachers' views about the use of WhatsApp, Facebook, and YouTube in the classroom? and ii) How do they use these Web 2.0 applications in the delivery of their lessons? Phenomenology was used as a research paradigm, and one-on-one, semi-structured interviews were the main sources of data collection to elicit rich descriptions of the teachers' views and experiences with Web 2.0 applications. Ten purposively selected teachers from two different provinces in South Africa participated in the study. All the teachers had more than fifteen years of teaching experience and taught in science-focused schools or technical high schools in the FET band. The findings show that, despite a lack of training and support from the local district offices, 7 of the 10 respondents had a positive disposition and epistemic openness toward WhatsApp, 1 of 10 responded positively to the use of Facebook, and all participants found YouTube to be an effective tool for lesson preparation. The findings have implications for teacher educators, and professional development programs are required to prepare and assist in-service and pre-service teachers with the dissemination of content in a technological, pedagogical space.
\end{abstract}

Keywords: Physical Science Teachers, Phenomenology, Technology-based Teaching, Web 2.0 Applications

\section{Introduction}

$\mathrm{D}$ ewey (1933) believed that the goal of teaching science in school is to assist and guide learners in understanding the natural world. To do so, he argued, teachers should allow their learners to investigate real problems and issues that reside in the difficulty that life presents, instead of holding the minds of learners' captive in memorizing longstanding facts and old ideas that lead to ancient solutions. Modern science is an open world, stretching beyond any assignable boundaries that schooling places on a child's mind. Simply put, one of the primary aims of teaching science in school should be for teachers to take their learners beyond the abstract world of concepts, definitions, theories, and mathematical formulas to "an experience" of the world that will develop and extend their ideas (Koopman 2017a). Teaching should thus be a systemic process that encourages independent and self-directed learning. Such teaching approaches will not only inspire modern learners to investigate their own questions of interest, but also encourage them to search for relevant information, formulate solutions, and apply these solutions in their own lives. This suggests that science teachers have an important role to play in designing innovative and creative learning spaces that nurture such values and stimulate a deeper understanding of science. According to Aleksić and Invanović (2013), modern-day learners, also referred to as "digital natives," are no longer interested in the direct verbatim transfer of information from a teacher to a learner; these learners need more technologically interactive approaches. Reilly (2012) argues that these digital natives flourish in situations that involve technologies that are visual, flexible, connected, interactive, and encourage collaboration. A pivotal text by Bourne and Seaman (2013), published almost seven years ago, suggests that one way to enhance independent, creative, and self-directed values in learners is to fuse the best of face-to-face instruction and online learning together. More recently, as a result

\footnotetext{
${ }^{1}$ Corresponding Author: Micheal M van Wyk, Preller Street, Muckleneuk ridge, Pretoria, 0003, Department of Curriculum and Instructional Studies, College of Education, University of South Africa, South Africa. email: vwykmm@unisa.ac.za
} 
of the rapid development of mobile technologies (e.g. smartphones, tablets, and apps), Wang and $\mathrm{Ma}$ (2017) similarly advocate for linking face-to-face instructional learning with the best of online technology. According to these authors, cell phone technology holds tremendous benefits for learners as it can provide visual images, greater flexibility for learning, interactive capacity, as well as the potential to connect learners inside and outside the classroom. For Leung (2017), such blended learning spaces have the pursuit of learning at their core in a way that is more efficient than what teachers may be able to accomplish on their own. In terms of teaching and learning physical science as a school subject, teachers are encouraged to integrate technology into their lessons. This is manifested in the legislated South African National Curriculum Statement in its subject-specific curriculum documents called the Curriculum and Assessment Policy Statement. These documents state that teachers are encouraged to link "science and technology effectively" (Department of Basic Education 2011; Republic of South Africa 2004) and they should promote "the construction and application of scientific and technological knowledge" by adopting learner-centered pedagogies, inquiry-based learning, and the promotion of "high knowledge" and "high skills" (Reddy 2005; Garrison, and Archer 2000).

A cursory glance at the literature shows that this is not happening and most physical science teachers are trapped in traditional pedagogies that are dull and far removed from the everyday realities of learners (Onwu and Stoffels 2005; Koopman 2017a). This claim that many schools in South Africa still do not have access to information and communication technologies (ICTs) is substantiated by Blignaut's (2002) report, Waghid's (2013) doctoral dissertation, and Vandeyar and Vandeyar's (2015) analysis of ICT policy implementation in schools. However, there is little research to determine where we currently stand in relation to the policy objectives. There is also a dearth of empirical studies of teachers' views, compliance, and competence with ICTs. This significant research gap prompted us to embark on an investigation of the views of "experienced" physical science teachers as it relates to their engagement with Web 2.0 technology, such as WhatsApp, Facebook, YouTube, and so forth, in two selected provinces in South Africa, namely the Western Cape and Gauteng.

Accordingly, this paper tries to answer two research questions: i) What are Further Education and Training (FET) physical science teachers' views about the use of WhatsApp, Facebook, and YouTube in the classroom? ii) How do they use these Web 2.0 applications in the delivery of their lessons? In search of effective blended learning pedagogical practices, we explore these questions to report how teachers engage with technology in and outside of the physical science classroom. This article also offers policy-makers, curriculum planners, teacher educators, and prospective physical science teachers an understanding of the challenges that influence and shape pedagogical decision-making in teaching science content. A related aim is also to explore their views on the benefits of Web 2.0 technology in teaching physical science.

\section{Rationale for the Study}

International studies affirm that teachers' professional "self" is deeply rooted in the beliefs and values related to the way they were taught and trained (Talbert 1996). According to Inan and Lowther (2010), teachers' beliefs and readiness have a critical impact on their decision to integrate technology into classroom practice. This study will show that it is important to look deeper into the totality of teachers' lived experiences rather than discrete and isolated moments to develop an understanding of teachers' views of Web 2.0 technology.

The term "Web 2.0," also referred to as "social computing," was coined by Cochrane (2005) and represents a modern description of the online tools available on the World Wide Web. These tools allow their users to create and share content through online posting. According to Bingimlas (2017), Web 2.0 technologies are effective teaching tools as they allow teachers to facilitate online collaboration, interaction, and sharing of information between learners. Bingimlas (2017) avers that there are hundreds of Web 2.0 applications that can help 
develop high-level skills and knowledge in our learners, but the top six are listed as blogs, wikis, social networking sites such as Facebook and Twitter, video sharing (YouTube), podcasts, and discussion forums.

Facebook is the world's largest online social media network. As Web 2.0 technology, Meintjes and Van Wyk (2020) reported the usefulness of a Facebook page in teaching business studies. It is commonly used as a communication tool, to post pictures and upload videos to share with others. Conversely, WhatsApp is a popular microblogging application that allows its users to send and receive short messages, images, and post videos online. It is the most popular social networking tool in South Africa, and it is much cheaper than Facebook as it requires less data. According to Wilson (2015), YouTube is rated as the most popular teaching and learning tool. Wilson (2015) reports that teachers regard YouTube as an invaluable teaching tool because it increases student engagement and reduces classroom management issues. Teachers typically use YouTube to download videos, learn from it, and repost to their students as a learning resource. This study is interested in South African physical science teachers' views on Web 2.0 technologies such as WhatsApp, Facebook, and YouTube, and how they use these online tools to communicate, collaborate, and disseminate information to their learners. Because social media networks have are such important communication tools (Akcaoglu and Bowman 2016), it will be interesting to determine how South African physical science teachers view these teaching tools.

Findings reported by Project Tomorrow (2010) in the UK showed that traditionally, teachers, parents, and administrators were opposed to the use of digital platforms such as Facebook, YouTube, and various other social media networks involving the use of cell phones. In recent years, there has been a shift in these attitudes. For example, Waghid (2013), a Grade 10 teacher, discovered in his doctoral work that the use of Facebook in his life sciences classroom is not only effective in assisting his learners to become more creative and independent, but is also a pedagogical pathway to a greater awareness of social justice.

Indeed, the search for answers to these kinds of explorations seems particularly apt for phenomenological research, as the findings directly reveal the teachers' views, use, and perceptions of Web 2.0 applications and the challenges they might face. The insights gleaned from this study can be used to construct appropriate professional development programs and training for pre-service teachers to make them aware of the benefits of mobile technology in the classroom, such as providing support for content, increasing learner interaction, stimulating greater interaction with peers, and extending learning time away from the classroom. Next, a brief review of the use of Web 2.0 technology in the classroom is provided.

\section{Literature Review}

Over the last two decades, we have witnessed a shift from a lifestyle independent of technology to a mode of being that is almost completely dependent on technology across the globe. One of the markets that benefitted most from technological advances was the cell phone industry. This is because every year, these industries upgrade their devices as advances in new knowledge are made in the sector. This market attracted the interest of children across the world as they were intrigued by various social media platforms such as WhatsApp, Facebook, and TikTok. These international technological developments in the cell phone industry created a sense of urgency for teachers to apply mobile technology in their lessons to empower their learners for the future. This shift to the use of technology in the classroom is important, as the fourth industrial revolution emerged almost unnoticed in South Africa with the influx of smart and connected machines and systems in so many spheres of society-for example, iPhones, Uber, banking apps, self-check-in machines at airports, and so forth - that they have come to seem normal.

Gilbert (2019) reported that South Africa has an increase of 81.72 percent smartphone users in 2018 compared to 47.2 percent smartphone users in 2016, of whom 89 percent (as of 2019) are part of social media communities. Consequently, Web 2.0 technology such as Facebook, 
WhatsApp, YouTube, Twitter, WeChat, and various other e- and $\mathrm{m}$ - social media networks have exploded across the country over the last ten years. Kwon and Yixing (2010) describe social media as involving activities, practices, and behaviors among communities of people who gather online and exchange information, knowledge, and opinions using conversation media. Over the years, social media has developed into effective and affordable communication tools. These networks were further advanced by the invention of smartphones and various other smaller technological devices such as Apple watches and Fitbits to extend their use to uploading and pasting high-quality pictures, audio-recording, and incorporating the latest WhatsApp phone call features; these are all becoming more affordable and therefore more accessible to a large majority of South Africans. Although social media networks were not developed to serve academic purposes, Levin and Bruce (2001) argue that they can be used to help learners discover, inquire into, and construct new ideas. Consequently, the use of social media networks in the classroom has become almost inescapable for teachers, since so many South African children have access to smartphones.

YouTube has become the most popular video-based Web 2.0 application since its creation in 2005. According to Snelson, Rice, and Wyzard (2012), millions of children, teachers, scholars, and researchers across the globe watch YouTube videos. At the end of its first five years, YouTube had more than two billion views per day, and users uploaded more than thirtyfive hours of video per minute. YouTube is also ranked among the top five most visited websites and has millions of video clips. The variety of videos posted on YouTube draws a wide spectrum of users (Snelson, Rice, and Wyzard 2012), although not much is known about the interests of its users. Martin (2012) reports that YouTube users can access different video clips anywhere and at any time, using a diverse number of terminals, including desktops, laptops, tablets, and cell phones. Moreover, Wilson (2015) points out that YouTube can be an effective tool to enhance autonomous learning if the videos are analyzed, differentiated, and directed toward clarifying the main components of a subject. This implies that smartphones can provide South African physical science teachers with a pathway to giving their learners a fuller pedagogical experience that could nurture independent and self-directed learning.

In his doctoral work, Waghid (2013) explored the use of Web 2.0 technologies such as YouTube and Facebook with Grade 10 life science learners to measure their effect on learning. His findings report that these technological tools stimulate the Grade 10 life science learners to solve scientific problems meaningfully. He also personally went through a "pedagogical breakthrough," since his learners became more critical and self-directed in that they constructed, deconstructed and reconstructed existing ideas in the learning process, which is difficult to achieve in a traditional classroom. Yuan et al. (2017), in agreement with Waghid, found that in the traditional classroom, these outcomes are difficult to achieve since the learners do not adequately engage in authentic tasks. According to them, this is the case because, in the traditional classroom, learners often experience a heavy cognitive overload that can demotivate them from learning. Other studies by Martin et al. (2018) report that social media networks provide teachers and learners with unlimited opportunities and possibilities for teaching and learning. They explain that Facebook gives teachers opportunities for connecting with their peers outside the classroom in a collaborative capacity, which could, in turn, create better teacher-learner relationships. According to Casserly and Smith (2008), a Web 2.0 environment does not only promote greater participation in the learning environment but also stimulates creativity, fresh ideas and insights, because teachers and learners can draw from a range of sources. Web 2.0 technologies afford learners flexible access to resources and flexible communication with others which, in turn, promotes effective learning as teachers are often constrained in what they can do during normal classroom time (Yuan et al. 2017).

According to Waghid and Waghid (2018), Web 2.0 applications can also create asynchronous communities of inquiry that could develop communities of learning. This means that online learning also provides learners with access to course content material or information 
at any given time. Therefore, it can create a sphere for continuous interaction with peers, resources, and various forms of information. Thorne (2003) holds the view that this approach (the use of e-/m-tools) can change the learning landscape from a more conservative, traditional and even authoritarian approach, to a more personalized and focused way of learning. For example, YouTube creates virtual learning spaces where teachers and learners are linked with subject specialists and experts in various parts of the country or the world at the press of a button. These experts can chat directly with learners via Skype or chatrooms, which can be augmented by video or audio conferencing. Garrison and Vaughn (2008) explain that one of the main advantages of e-learning is the ability to move beyond theoretical constructs toward 3D imaging, where teachers inspire their learners to come up with real solutions for complicated problems. In other words, the real benefit of e- and m-learning lies in its potential. Casserly and Smith (2008) concur that e-learning can convert the classroom from a traditional teachercentered space to a more learner-centered site of learning.

\section{Theoretical Framework}

A large and growing body of literature has investigated Web 2.0 technologies in contact, blended, or online teaching spaces. For the purpose of investigating physical science teachers' views and use of technology in the classroom, specific theories underpin this study, namely the connectivity theory and actor-network theory. Although these two theories have an integrative theoretical framework and fall under sociomaterialism, this study will theoretically draw on connectivism to explore physical science teachers' lived experiences of using Web 2.0 technologies such as Facebook, WhatsApp, and YouTube to communicate, engage, and teach the subject (for full detail on sociomaterialism, see Hannon 2013). According to Fenwick and Edwards (2010), connectivism promotes dialogue and dialogicality between actors using various technological or social media platforms. Connectivism therefore creates learning spaces when knowledge is actuated through the process of teachers connecting to and proving information to learners in a network learning space. This idea of connectivism is closely linked to the idea of actor-network learning or network learning as various scholars (Siemens 2005; Downes 2006) used the phrase "network learning" to describe and explain how children learn using networks as a learning platform.

Connectivism, Siemans (2005) notes, is seen as a progression from traditional theories like behaviorism and constructivism, which took place in a time when technology was not yet established and refined, hence the absence of networks. He writes, "Behaviorism, cognitivism, and constructivism are the three broad learning theories most often utilized in the creation of instructional environments. These theories, however, were developed in a time when learning was not impacted through technology" (Siemen 2005, 17). Three aspects of critical importance for those using network theory include i) skills, ii) the ability to seek information, and iii) the ability to filter information. This study is particularly interested in teachers' views about the use of Web 2.0 tools, and whether the teachers have the skills to use Web 2.0 technology such as WhatsApp, Facebook, and YouTube in their lessons.

\section{Methodology}

\section{Research Design}

This study adopted a process of phenomenological data construction in which interviews and field notes were the main sources for data collection to reveal the direct voices of each research participant with respect to their views of technology. What makes phenomenology different from other research approaches is that it does not offer a theory that researchers can use to explain the world of participants; instead, it offers the possibility of describing the lived experiences of the participants based on their personal reflections of events as they happen (Van Manen 1990). This means that the authors, as phenomenologists, have to bring a specific kind of sensitivity to the 
data-construction process (Van Manen 1990). It involves being totally receptive and avoiding the pitfalls of being misled, side-tracked or enchanted by extraneous elements. Other behavioral expectations, as a phenomenologist, include avoiding getting carried away by unreflective preconceptions and personal emotions, and allowing the participants to speak freely.

Instead of mathematising the data using inferential statistics followed by theorizing people's experiences - generally based on a reduction of the truth, which represents what is customary in quantitative research-phenomenology focuses on the "priority of significance to fact, relation to substance, and understanding to knowledge" (Weinsheimer 1995, 178). While most published studies investigated teachers' views about technology by employing a quantitative approach, this study is more interested in the existential constitution of being in the realm of the factual potentiality of being (Heidegger 1962). Therefore, as a methodology, phenomenology reports on peoples' "whole being" and their choices for an authentic experience as a presentation of the "self," and how a person perceives and thinks about the things in which they are engaged. In simple terms, phenomenology is interested in understanding the "lived experiences" of others, which in this study specifically means understanding the lived experiences of physical science teachers in coming to terms with technology. This study is thus interested in the teachers' views, perceptions, and experiences with different Web 2.0 applications. This objective, Husserl (1967) argues, is accurately presented by describing the data as divulged verbatim by the participants.

\section{Sampling}

Ten physical science teachers were purposively selected. Datallo (2010) asserts that purposive sampling is used, among other approaches, to select a small subsample to closely examine and compare typical and unusual or extreme elements. From this perspective, an array of factors such as province, race, qualifications, age, gender, region, and teaching experience, the quintile index rating of the school and the focus group classification were considered in the selection process. Table 1 provides an overview of the participants in this study.

Table 1: Overview of the Research Participants

\begin{tabular}{|c|c|c|c|c|c|c|c|}
\hline Teacher & Province & Age & Race & Gender & $\begin{array}{c}\text { Experience } \\
\text { (years) }\end{array}$ & Qualifications & $\begin{array}{c}\text { Major } \\
\text { Subject }\end{array}$ \\
\hline $\mathbf{A}$ & WC & 55 & $\mathrm{C}$ & Male & 28 & $\mathrm{BSc}$ & $\begin{array}{c}\text { Chemistry } \\
\text { Math }\end{array}$ \\
\hline B & WC & 62 & $\mathrm{C}$ & Male & 38 & $\mathrm{BSc}$ & $\begin{array}{l}\text { Physics } \\
\text { Math }\end{array}$ \\
\hline C & WC & 45 & $\mathrm{C}$ & Female & 16 & BEd (Science) & $\begin{array}{l}\text { Science } \\
\text { Math }\end{array}$ \\
\hline D & WC & 48 & $\mathrm{C}$ & Male & 28 & BSc, PGCE & Chemistry \\
\hline $\mathbf{E}$ & WC & 45 & $\mathrm{C}$ & Female & 15 & BEd (Science) & $\begin{array}{l}\text { Physical } \\
\text { Science }\end{array}$ \\
\hline $\mathbf{F}$ & WC & 53 & $\mathrm{C}$ & Female & 26 & BEd (Science) & $\begin{array}{l}\text { Physical } \\
\text { Science }\end{array}$ \\
\hline G & Gauteng & 38 & A & Male & 15 & BEd (Science) & $\begin{array}{l}\text { Physical } \\
\text { Science }\end{array}$ \\
\hline H & Gauteng & 53 & $\mathrm{~W}$ & Female & 15 & $\begin{array}{c}\text { BSc } \\
\text { (Metallurgy) }\end{array}$ & Chemistry \\
\hline I & Gauteng & 55 & $\mathrm{C}$ & Female & 24 & BEd (Science) & $\begin{array}{l}\text { Physical } \\
\text { Science }\end{array}$ \\
\hline $\mathbf{J}$ & Gauteng & 48 & A & Male & 16 & $\mathrm{BSc}$ & $\begin{array}{c}\text { Chemistry, } \\
\text { Physics }\end{array}$ \\
\hline
\end{tabular}

Key per Race: $C=$ Coloured; $A=$ African; $W=$ White [South African Legislation by Racial Groups] Source: Koopman, Van Wyk, and Koopman 2020 
The ten teachers who participated in the study resided in the Western Cape (6) and Gauteng (4). Only teachers from Gauteng and the Western Cape were selected to participate in the study, because these are the two wealthiest provinces (highest income per capita) in South Africa. Therefore, learners from these provinces are more likely to be able to afford smartphones and have greater access to Web 2.0 technology than those from the other provinces. The teachers who participated in this study had to teach in a science-focused school or a technical school, where the teachers and learners had access to Wi-Fi or internet facilities. The teachers also had to have at least fifteen years' experience in teaching physical science.

\section{Interviews}

As is typical in phenomenological research, open-ended, unstructured interviews were conducted with each participant to elicit rich descriptions of their views. This method provided each research participant with the opportunity to share their stories about how they view WhatsApp, Facebook, and YouTube, and how they use these platforms in the teaching and learning process. According to Price (2002), artful interviewing takes place when the researcher knows and understands the ways in which people's thoughts, beliefs, and actions correspond. As such, the laddered technique of questioning, as advocated by Price (2002), was used to elicit rich descriptions of their lived world. Laddered questions operate on three levels: i) inviting descriptions aimed at setting the scene and indicating the researcher's interest in what he/she has to say or offer; ii) knowledgeable or invasive questions are asked later in the interview when the participants have shown signs of relaxation or comfort. This involves questions such as: What do you think? How do you feel? and iii) questions about personal philosophy. These are the most invasive questions as they focus on personal beliefs, values and deep-seated feelings - matters that lie at the core of the participants' personal identity. Asking questions at this level is akin to asking questions about who you are and, unless the interviewer is careful, they may leave the participant feeling that the researcher is judging them. We decided to divide the interview into two parts to apply the laddered technique effectively.

The first part of the interview focused only on questions such as how they were taught and what they considered effective teaching strategies; what kinds of cell phones they had and how familiar they were with these phones; whether the school had accessible internet or Wi-Fi; and whether they had policies on the use of cell phones. These questions allowed us to get to know the participants on a superficial level. In order to win their trust, it was important to listen carefully to what they had to say. We also showed empathy through body language and tone of voice when responding to participants' answers and descriptions of their lived world. Their answers to these questions provided insight into what they considered as effective instructional methods, the resources of their schools, and their views about cell phones. The data also provided an overall perspective on how participants learned science and whether they had considered using digital platforms in the classroom. It also assisted our understanding of how they were pre-discursively shaped and influenced for careers in science.

The second part of the interview started with questions to elicit information, such as how they taught the subject and whether they considered social media platforms such as Facebook, YouTube and WhatsApp to be useful in their teaching. For example, did they value social media as teaching tools, or was their focus mainly on preparing learners for tests and examinations. Furthermore, we focused on whether participants had transformed their own practices from the way they were taught science at high school or university, to the way that they were now expected to use technology in the classroom. The focus then shifted to more invasive questions that invited emotional responses, such as why they were open or closed to the idea of using Web 2.0 technology, what they thought the benefits were, successes or disadvantages, and failures in their use of technology. How did they cope with the challenges, did they use these social media platforms and YouTube, and were they useful when planning 
and teaching their lessons? The answers to these questions allowed us entry into participants' personal philosophies and deep-seated emotions about the use of technology. We attempted to abstain from imposing any preconceived or a priori views of the world by placing ourselves in participants' shoes to view the world through their experiences without any form of bias.

\section{Data Framework}

The main focus of the analysis was to present the participants' views on technology and what it means to them as described from their personal accounts. Our main objective was to search for meaning and structure that essentially answered the primary research questions. Thus, each transcript was read with a meaning-expanding focus as we wanted to present fresh insights into the phenomenon. For the purpose of extracting data from the interviews, we phrased the following questions: What are the physical science teachers' views of WhatsApp, Facebook, and YouTube? How do they feel about these applications, and why do they feel the way they do? This meant we had to move back and forth between the data and the emerging meanings in order to validate the main research findings. We also had to adopt a reflective stance toward understanding the participants' experiences.

Heidegger's philosophy allowed us to unpack the context in which the teachers were taught and the teaching strategies they were exposed to as school learners and at university. His conceptualization of being (dasein) allowed us to engage with each of the participants' transcripts in terms of how they comprehended and perceived technology, how they taught and were using technology, and whether they were subconsciously aware of the benefits of these technological tools in the teaching and learning process.

\section{An Overview of the Transcript Analysis}

After iteratively reading each transcript, we highlighted key words in every transcript as they related to the foundational experience and meaning given to technology. We collated these key terms, phrases, and sentences after removing all extraneous, unrelated, and superfluous items to derive the central themes in each participant's transcript. This allowed us to gain insight into each participant's disposition to technology. The interpretive themes were constructed by highlighting high-frequency words and the priority given to certain words in their responses. We selected two interpretive themes. These themes were augmented with the first author's personal experiences as an ex-teacher of physical science and adumbrated some literature related to the use of technology and its advantages to learning. We then crafted descriptions of what we thought reflected participants' views as expressed from their perspectives.

\section{Results}

The analysis suggested that there were many factors that influenced the teachers' views about the use of Web 2.0 applications. The teachers' limited openness or reluctance to use these tools was, to some extent, clearly related to: i) how they were trained as learners and as teachers; ii) internet availability and stability, iii) the social status of the community in which the schools were located, iv) the lack of support and training or professional development programs on how to use social media networks (especially Facebook) in the classroom; and iv) learner issues, such as discipline.

\section{Teacher Background and Formal Training on How to Use Technology}

The ten teachers who participated in this study were spread across three generations: three were from the baby boomer generation, six were from Generation X, and one was a Xennial. The 
baby boomers (teachers A, B, and I) completed their school careers and university teacher training at a time when no attention was devoted to technology such as computers, laptops, and the small electronic devices ubiquitous in modern society. During this period, the internet and Web 2.0 applications did not yet exist in their world. The focus of their training, as pointed out by teacher B, was:

To sit passively in class while my teacher was teaching. My teachers only used the blackboard, a duster, the textbook and at times an overhead projector. These were the main resources. So, we did not have computers nor did our teachers and lecturers showed us how to use computers.

The majority of the teachers belonging to Generation $\mathrm{X}(\mathrm{C}, \mathrm{D}, \mathrm{E}, \mathrm{F}, \mathrm{H}$ and $\mathrm{J})$ completed their school careers in poorly resourced schools with staff that had no formal training in technology. However, they did receive their teacher training during a period when the internet was operational in South Africa, but all their teachers and lecturers came from an older generation, and they had no practical exposure to technology and other online Web 2.0 applications. Consequently, these teachers were not formally made aware of the new technology and the internet, and therefore had very little exposure to electronic and mobile devices. Although teacher $\mathrm{G}$ completed his school career when the internet was widely used in both schools and universities in the 1990s, mobile devices such as smartphones and online tools were new. When he was asked to describe the teaching methods and strategies he employed for his Grades 10 to 12 Physical Science classes, he said:

My Grade 10, 11, and 12 teachers were terrible...so as a result I suffered. Then I went to Grade 11, still the same teacher, to a point whereby I didn't know if I would go to Grade 12. Luckily I did make it and we complained and say to the principal, we don't want this teacher in our Grade 12. So that is how bad it was, we did not have computers nor did we know how to work on it.

When asked whether he had any training at university, he said:

I was formally introduced to ICTs in a different course at the university where I studied to be a teacher. It was very enjoyable...I liked working with computers so I know how to work on them... The problem is they did not use it in their classes and they did not show us how to use it.

Thus, the way the teachers were prepared during their training as learners and teachers at university, to some extent, influenced their disposition towards using technology in their own classrooms. For example, teacher $\mathrm{G}$, who had received some formal instruction in ICTs at university, described himself as "very fond of technology," and he was the only person who showed epistemic openness to the use of Facebook as a pedagogical tool. The other participants rejected the use of Facebook outright, but showed some openness to WhatsApp and YouTube. The reasons for their responses are discussed in the sections that follow. The data on teachers' views about the use of Web 2.0 applications is illustrated in Table 2, and showed considerable variation. 
Table 2: Teachers' Views on Web 2.0 Technology

\begin{tabular}{|c|c|c|c|}
\hline Teacher & WhatsApp & Facebook & YouTube \\
\hline A & YES & NO & YES \\
\hline B & NO & NO & YES \\
\hline C & YES & NO & YES \\
\hline D & NO & NO & YES \\
\hline E & YES & NO & YES \\
\hline F & NO & NO & YES \\
\hline G & YES & YES & YES \\
\hline H & YES & NO & YES \\
\hline $\mathbf{I}$ & YES & NO & YES \\
\hline $\mathbf{J}$ & YES & NO & YES \\
\hline
\end{tabular}

Source: Koopman, Van Wyk, and Koopman 2020

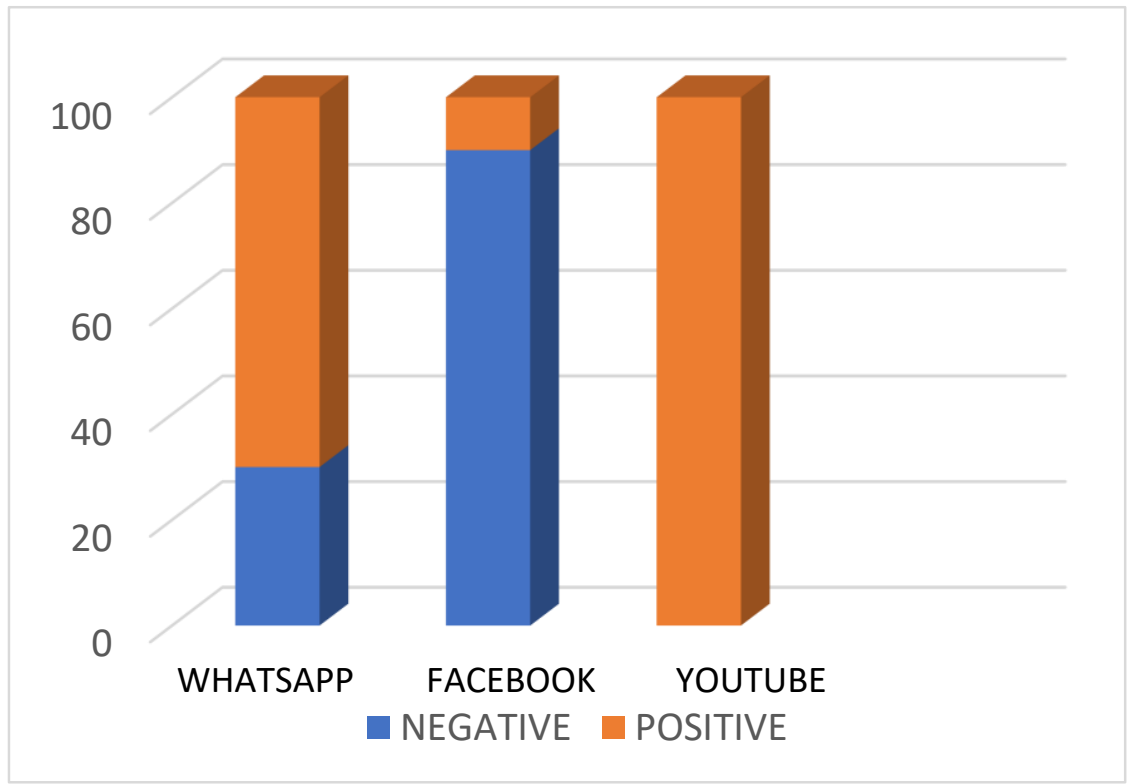

Figure 1: Teachers' Views about the use of Web 2.0 Application Source: Koopman, Van Wyk and Koopman 2020

As illustrated by Table 2 and Figure 1, seven of the ten teachers showed an openness to using WhatsApp, while three did not approve of its use. Most of the teachers described WhatsApp as a valuable teaching tool. Teacher A's comment summarizes this finding: "Although I was not trained as a child and as a teacher on how to use it, I encourage my learners to use it." Others pointed out that they wanted to use it in class, but the children did not have the discipline to use it for educational purposes. Teachers B and D shared similar sentiments as teacher F, who said, "our school does not have a cell phone policy and we have no control over the learners when they use their phone." Regarding Facebook, only one of the participants used Facebook, and the remaining nine rejected it. The teacher who approved is classified as a Xennial, and therefore can be considered a digital native compared to the other participants, who grew up in the 1970s and 1980s. All the teachers had positive views about the use of YouTube and saw it as an effective teaching tool. This means that YouTube was also regarded as the most popular teaching and learning tool. Teacher B's comment explains why they all like YouTube: "concerning YouTube, it very easy to use, unlike WhatsApp and Facebook, where I need help to use it. It is really valuable to me when I prepare for lessons." 


\section{Factors Influencing the Use of Web 2.0 Applications Internet Connectivity and Stability}

In the Western Cape, teachers B, C, and F taught in quintile two schools and listed internet access and internet instability as significant concerns. For example, teacher B stated that "sometimes the internet is working, sometimes it's not working; you can't work like that." Teacher J, who taught in Gauteng, made a similar comment and pointed out that "it's a problem to plan in a lesson the use of a YouTube video and then find out you can't connect to the internet...it's really a serious problem at this school." Other challenges mentioned by teachers A and D were that, although most of the learners had a cell phone, "those that do not feel left out."

\section{Teacher Training and Support}

With reference to training, all the teachers in the Western Cape shared similar sentiments that they did not get support from the Department of Basic Education, and no training was offered on how to use social media in their teaching practice. This claim was substantiated by participant B, who said "I never see the subject advisors...so we never had anyone showing us how to use cell phones." Teacher C stated: "My learners do not have discipline and therefore, they will use their cell phones for anything but educational reasons. Our school does have a cell phone policy and therefore we were allowed it in the classroom." She also explained:

Our school provided learners with 24-hour free Wi-Fi but instead of using it to study, they (learners) gave the passwords to the parents who used it for chatting. We immediately changed the passwords and stop the free connection.

In strong contrast, the teachers in Gauteng were all very positive about the use of social media tools in the science classroom. They all pointed out that regular workshops and training were offered to teachers and assistance was provided on how to use cell phones and various other devices, such as tablets and iPads, in the classroom. When they were asked what they think the benefits of technology are, they offered the following explanations. The reasons mentioned for their positive responses to WhatsApp (7 out of 10$)$ and YouTube (100\%) were: i) They all had WhatsApp profiles; therefore, they found it easy to use to send audio, video or photo files to colleagues and/or learners; ii) They could communicate with colleagues and/or learners (text messaging or audio-recording to explain or describe a phenomenon); and iii) They knew how to download videos from YouTube and post them on WhatsApp. Teachers B, D, and F expressed a similar view to that of participant F, who said "I feel my time at home is my time, learners and the department must respect that. I will help my learners as much as I can but I am not going to allow them to swallow me up."

\section{Lack of Skill and Competence in Using Web 2.0}

In Gauteng, only teacher I was enthusiastic about the use of Facebook compared to none in the Western Cape. The remaining nine who were pessimistic about the use of Facebook provided the following reasons: i) They found Facebook complex because they did not know how to set up a Facebook profile page for the group; ii) They did not receive any training from the Department of Basic Education on how to use Facebook as a teaching tool; and iii) Most parents did not allow their children to use Facebook. Teacher G showed an openness to the use of Facebook and pointed out that i) Facebook is a "better communication tool than WhatsApp because we can follow postings which help us identify behavioral problems, to give learners emotional support." $\mathrm{He}$ (Teacher G) ii) used it mainly for communication purposes to "remind learners of due dates of assignments, tests and examinations"; and iii) it is "a lot more colorful than WhatsApp." The findings showed that the location of the school and the prevailing social dynamics seem to have their own modalities of meaning in terms of the teachers' use of technology. 


\section{Summary of the Main Findings}

Table 3 is a summary of the key words that appeared in the transcripts, emphasizing how the teachers engaged with the different technological tools in the classroom:

Table 3: How Teachers Engaged with Web 2.0 Technology

\begin{tabular}{|c|c|c|c|}
\hline Teacher & WhatsApp & Facebook & YouTube \\
\hline $\mathbf{A}$ & $\begin{array}{l}\text { Notification and } \\
\text { communication, discussion of } \\
\text { work }\end{array}$ & Not at all. & Downloading of videos \\
\hline B & NO & Not at all. & $\begin{array}{l}\text { Downloading of videos to } \\
\text { prepare lessons and play in } \\
\text { class }\end{array}$ \\
\hline $\mathbf{C}$ & $\begin{array}{l}\text { Notification and } \\
\text { communication, discussion of } \\
\text { work }\end{array}$ & Not at all. & $\begin{array}{l}\text { Preparing for lessons and } \\
\text { playing in class }\end{array}$ \\
\hline D & NO & Not at all. & $\begin{array}{l}\text { Preparing for lessons and } \\
\text { playing in class }\end{array}$ \\
\hline $\mathbf{E}$ & $\begin{array}{l}\text { Notification, communication, } \\
\text { guidance for problem solving; } \\
\text { audio-recordings and pictures }\end{array}$ & Not at all. & $\begin{array}{l}\text { Preparing for lessons and } \\
\text { playing in class }\end{array}$ \\
\hline $\mathbf{F}$ & NO & Not at all. & $\begin{array}{l}\text { Preparing for lessons and } \\
\text { playing in class }\end{array}$ \\
\hline $\mathbf{G}$ & $\begin{array}{l}\text { Notification and } \\
\text { communication, posting audio- } \\
\text { recordings, pictures }\end{array}$ & $\begin{array}{l}\text { Advise, } \\
\text { emotional } \\
\text { support, } \\
\text { notification of } \\
\text { due dates. }\end{array}$ & $\begin{array}{l}\text { Preparing for lessons and } \\
\text { playing in class }\end{array}$ \\
\hline $\mathbf{H}$ & $\begin{array}{l}\text { Posting of question papers, } \\
\text { homework and notification }\end{array}$ & Not at all. & $\begin{array}{l}\text { Preparing for lessons and } \\
\text { playing in class }\end{array}$ \\
\hline $\mathbf{I}$ & $\begin{array}{l}\text { Posting of question papers, } \\
\text { homework and notification }\end{array}$ & Not at all. & $\begin{array}{l}\text { Preparing for lessons and } \\
\text { playing in class }\end{array}$ \\
\hline $\mathbf{J}$ & $\begin{array}{l}\text { Discussion platform for } \\
\text { homework, peer-peer tutoring } \\
\text { and challenging question }\end{array}$ & Not at all. & $\begin{array}{l}\text { Preparing for lessons and } \\
\text { playing in class }\end{array}$ \\
\hline
\end{tabular}

Table 3 indicates that teachers $\mathrm{A}$ and $\mathrm{C}$ in the Western Cape engaged with WhatsApp in a very superficial pedagogical way that does not nurture deep learning, which would include posting questions and audio-recordings to explain the work and peer-to-peer learning. Only teacher E made a more meaningful attempt to use WhatsApp in his practice by inviting discussion and posting learning material. Teachers B, D, and F indicated that they did not use WhatsApp as a teaching tool. It is significant that teachers B, D, and F all grew up in an era with no digital technology, nor did they receive any training as learners or pre-service teachers in how to use WhatsApp in the classroom. Furthermore, the Department of Basic Education did not provide any professional development training in terms of WhatsApp's use in practice. What stood out for teachers B, D, and F is their aversion to WhatsApp, because of their fear of the unknown, or the fear of being compelled to use WhatsApp in their classrooms and not knowing how to use it effectively. Also, the culture of performativity, where the focus is on completing the Grade 12 syllabus and adequately preparing learners for the examinations could be one of the main reasons why these teachers were not open to adopting digital platforms in the 
delivery of their lessons. Furthermore, the fear of being confronted with the challenge of how to use it effectively was another concern, as most of the teachers did not receive formal training in how to use Web 2.0 applications. Moreover, with twenty years of experience, they felt the need to slow down after school. Drawing from the primary author's own experiences as a science teacher, the only time to slow down is after school to reflect on and process events.

Teachers $\mathrm{G}, \mathrm{H}, \mathrm{I}$, and $\mathrm{J}$ in Gauteng engaged more effectively with WhatsApp as a pedagogical tool. They incorporated WhatsApp in a more interactive way by posting questions, audio-recordings and pictures. One of the beneficial uses of WhatsApp that all participants (in Gauteng) agreed on is that it is an "effective peer-to-peer tutoring tool," as teacher G noted. Another benefit that all the participants (Western Cape and Gauteng) mentioned was that WhatsApp helped to improve their relationship with their learners. Teachers A, C, G, and J commented that they lay down very strict ground rules for WhatsApp groups. Inappropriate comments, mocking, insults, and false information were prohibited in the group. Only postings about work were permissible. In this regard, teachers I and J both said, with reference to learners who abuse the tool, that they were "quick to remove their names from the group as a form of punishment, but that also depend on the offence. If it's very serious they are removed for a whole month." In other words, all the teachers understood the need to be as professional as they can be to create appropriate learning spaces. The teachers pointed out that they used WhatsApp mainly after hours and not in class. They stated that they were in control of their own time in terms of how much time they choose to spend on it. Teacher G said, "Sometimes I have a lot of work and no time, but then there are days that I can spend plenty of time in the chat groups." This means time spent on WhatsApp can range from five minutes up to two hours per day after school.

All the teachers found YouTube more popular and useful than the other social media networks. All the participants stated they used YouTube videos to i) introduce their lessons, ii) explain very complex concepts or consolidate the content, and iii) improve their personal understanding of the content. For example, teacher C's comment on how she engaged with YouTube in the classroom summarizes the general view of the teachers:

I like YouTube videos, because most of the time after I watch it I understand the work better. My main reason for downloading these videos is to help my learners but most of the time these videos help me. I can also see that most of my learners really enjoy these videos. Those learners' parents can afford it come to me and ask Miss did you watch this video or that video. It looks like these videos are really a godsend.

Teacher A explained how his learners benefitted from YouTube in the following excerpt:

If I could, I would play these videos for my students the entire lesson, but I know if they don't do very well, they will say it's because I only let my learners watch these videos. But I must say I can see it really help my students. Every evening when I prepare I look for good videos that is easy for my learners to follow and understand the work.

When asked how much of the lesson time they allow their learners to watch YouTube videos, lengths ranged from five to twenty-five minutes. For example, B said:

Sometimes when I teach a topic like electricity, I let them watch how an instructor solves a problem just so that they can see and follow the steps. This can take five minutes, at times even fifteen minutes but I do get concerned if I let them watch too much videos. 


\section{Discussion of Findings}

The findings in this study showed that YouTube is the most popular Web 2.0 application in and outside of the science classroom. According to Lee et al. (2017), YouTube plays an invaluable role in facilitating online self-directed and independent learning. Apart from the positive learning environment that YouTube provides to its users, it also covers many open course materials for science. This ranges from formal lectures to practical activities. Ranga (2017) lists the following pedagogical advantages that YouTube offers chemistry students: i) 24/7 access at a self-directed pace, ii) learning gets extended beyond the classroom, and iii) the YouTube content takes them beyond the scope of their curriculum. These benefits correspond with the findings of this study, as YouTube promoted self-directed learning among the teachers, and they could use this space to promote a deeper understanding of some scientific concepts. They could also use YouTube anywhere and anytime, even to enter a digital laboratory and observe how scientists perform practical work and link it to a specific subset of the content. In line with Aragon's (2007) finding, the teachers in this study emphasized that YouTube is easily accessible, with the potential to spark insightful discussions about the content. Hence, it is also considered one of the most effective teaching tools (Ranga 2017), which is consistent with the findings of this study.

Regarding social media networks as a Web 2.0 teaching tool, the findings show that WhatsApp was more popular than Facebook among the ten physical science teachers. According to Akgunduz and Akinoglu (2016), WhatsApp is very flexible and user-friendly. Jones et al. (2010) explain this by pointing out that blended learning is best demonstrated when teachers blend their face-to-face contact sessions with social media networks, such as WhatsApp and Facebook. They aver that these social media networks are powerful tools to communicate effectively and support teaching and assessment processes. The views reported by the teachers in this study are also consistent with those of Blackey et al. (2010), in that the teachers all agreed that WhatsApp, as a "communicative and supportive tool," can play a major role in guiding learners to deal with questions, tasks and assignments. This finding is further corroborated by the empirical work done by scholars who report how teachers use WhatsApp and Facebook to stay in touch with their learners and offer them emotional support during difficult times (Koopman 2018; Akgunduz and Akinoglu2016; Dube and Lubben 2011).

\section{Conclusion and Recommendation}

The findings of this study reveal the importance of teachers' disposition toward WhatsApp, Facebook, and YouTube, and their competence in using these technological tools to develop teaching strategies that could create innovative learning opportunities. The two main findings that emerged from the study are: i) that teachers need better support from the various district offices in the Western Cape through professional development programs to improve their foundational knowledge on how to use Web 2.0 technology in the classroom; and ii) teacher educators should train and prepare pre-service teachers more adequately in the use of these technologies for the future.

In both instances, the support and training offered to teachers and pre-service teachers must be continuously revised and updated, since technology constantly changes. According to Inan and Lowther (2010), teachers need support and encouragement to become lifelong learners themselves. This means they need to upgrade their capabilities and master various technological skills and the pedagogical knowledge required to do so. This will result in a shift from conservative, traditional pedagogies, to more liberal technologically oriented approaches. In the current study, we examined only a small sample of science teachers' views on the use of Web 2.0 technologies in the classroom. Further research is needed to explore a larger sample in order to compare similar school subjects and the social sciences. 


\section{Acknowledgment}

We are grateful to the anonymous reviewers for their constructive and insightful comments, as well as the editor to improve the scholarly quality of the paper. A word of appreciation to the Physical Science teachers of the Western Cape and Gauteng Department of Basic Education, who voluntary participated in this study. We are thankful to the National Research Foundation for their financial support (grant reference number TTK 160504163990). Finally, the university language editing team for editing the paper. All views and comments expressed in this paper are those of the authors.

\section{REFERENCES}

Aragon, Janni. 2007. "Technologies and Pedagogies: How YouTubing, Social Networking, and other Web Sources Complement the Classroom." Feminist Collections: A Quarterly of Women's Studies Resources 28 (4): 45-45.

Akgunduz, Devrim, and Orhan Akinoglu. 2016. "The Effect of Blended Learning and Social Media-Supported Learning on the Students' Attitude and Self-Directed Learning Skills in Science Education." Turkish Online Journal of Educational Technology 15 (2): 106-115. https://files.eric.ed.gov/fulltext/EJ1096457.pdf.

Akcaoglu, Mete, and Nicholas David Bowman. 2016. "Using Instructor-led Facebook Groups to Enhance Students' Perceptions of Course Content." Computers in Human Behavior 65 (1): 582-590. https://doi.org/10.1016/j.chb.2016.05.029.

Aleksić, Veljk, and Mirjana Ivanović. 2013. "Blended Learning in Tertiary Education: A Case Study." Proceedings of the 6th Balkan Conference in Informatics (BCI'13), 96-103, Thessaloniki, Greece.

Bingimlas, Khalid Abdullah. 2017. "Learning and Teaching with Web 2.0 Applications in Saudi K-12 Schools.” Turkish Online Journal of Educational Technology 16 (3): 100-115. https://files.eric.ed.gov/fulltext/EJ1152646.pdf.

Bourne, Keith, and Jeff Seaman. 2013. Changing Course Ten Years of Tracking Online Education in the United States. New York: Babson Survey Research Group and Quahog Research Group, LLC.

Blignaut, Selwyn S. 2002. "Matching Computer Competencies with Education Competencies in Preservice Teacher Training." South African Journal of Higher Education 16 (3): 109-126. https://doi.org/10.4314/sajhe.v16i3.25224.

Casserly, Catherine M., and Marshall S. Smith. 2008. "Revolutionizing Education through Innovation: Can Openness Transform Teaching and Learning?" In Opening Up Education: The Collective Advancement of Education through Open Technology, Open Content, and Open Knowledge, edited by Toru Iiyoshi and M. S. Vijay Kumar, 261-276. Cambridge, MA: MIT Press.

Cochrane, Thomas. 2006. "Learning with Wireless Mobile devices and Social software." Proceedings of the 23rd Annual Ascilite Conference: Who's learning? Whose technology? University of Sydney, Australia. http://citeseerx.ist.psu.edu /viewdoc/download?doi=10.1.1.116.8457\&rep=rep1\&type=pdf.

Datallo, Patrick. 2010. "Ethical Dilemmas in Sampling." Journal of Social Work Values and Ethics 7 (1): 1-14. https://jswve.org/download/2010-1/2dattalo-Ethical-dilemmas-insampling.pdf.

Department of Basic Education. 2011. National Curriculum and Assessment Policy Statements (CAPS) for Economics Grade 10-12. Government Printers, Gazette No. 34600: Pretoria. 
Dewey, John. 1933. How We Think. Boston: D.C Publishers.

Downes, Stephen. 2010. "Learning Networks and Connective Knowledge." In Collective Intelligence and E-Learning 2.0: Implications of Web-Based Communities and Networking, edited by Harrison Hao Yang and Steve Chi-Yin Yuen, 1-26. Hershey, PA: IGI Global. http://doi.org/10.4018/978-1-60566-729-4.ch001.

Dube, Turu, and Fred Lubben. 2011. "Swazi Teachers' Views on the Use of Cultural Knowledge for Integrating Education for Sustainable development into Science Teaching." African Journal of Research in Mathematics, Science and Technology Education 15 (3): 68-83. https://doi.org/10.1080/10288457.2011.10740719.

Fenwick, Tara, and Richard Edwards. 2010. Actor Network Theory in Education. London: Routledge.

Garrison, D. Randy, and Walter Archer. 2000. A Transactional Perspective on Teaching and Learning: A Framework for Adult and Higher Education Advances in Learning and Instruction Series. New York: Elsevier.

Garrison, D. Randy, and Norman D. Vaughan. 2008. Blended Learning in Higher Education: Framework, Principles, and Guidelines. London: John Wiley \& Sons.

Gilbert, Paula. 2019. "SA Smartphone Penetration now at over $80 \%$, says ICASA." ITWeb, April 3, 2019. https://www.itweb.co.za/content/GxwQDM1AYy8MlPVo.

Hannon, John. 2013. "Incommensurate Practices: Sociomaterial Entanglements of Learning Technology Implementation." Journal of Computer Assisted Learning 29 (2): 168-178. https://doi.org/10.1111/j.1365-2729.2012.00480.x.

Heidegger, Martin. 1962. Being and Time. Translated by J. Macquarrie and E. Robinson. London: Blackwell Publisher.

Husserl, Edmund. 1967. "Phenomenology." Edmund Husserl's Phenomenology. Pittsburgh: Duquesne University Press.

Inan, Fethi A., and Deborah L. Lowther. 2010. "Laptops in the K-12 Classrooms: Exploring Factors Impacting Instructional Use.” Computers \& Education 55 (3): 937-944. https://doi.org/10.1016/j.compedu.2010.04.004.

Jones, Norah, Haydn Blackey, Karen Fitzgibbon, and Esyin Chew. 2010. "Get Out of MySpace!" Computers \& Education $54 \quad$ (3): 776-782. https://doi.org/10.1016/j.compedu.2009.07.008.

Koopman, Oscar. 2017a. "Harnessing the Full Use of the Senses in the Science Classroom." In Science Education and Curriculum in South Africa, edited by Oscar Koopman, 141-163. New York: Palgrave Macmillan. https://doi.org/10.1007/978-3-319-40766-1_7. 2017b. Science Education and Pedagogy in South Africa. New York: Palgrave Macmillan. https://doi. 10.1007/978-3-319-40766-1 .

2018. "Towards Decolonizing Teaching Strategies: How to 'Domesticate' and 'Infuse' Western Science with Indigenous Knowledge.” Journal of Education 74 (1): 102-115. https://doi.org/10.17159/2520-9868/i74a07.

Kwon, Ohbyung, and Yixing Wen. 2010. "An Empirical Study of the Factors Affecting Social Network Service Use." Computers in Human Behavior 26 (2): 254-263. https://doi.org/10.1016/j.chb.2009.04.011.

Lee, Chei Sian, Hamzah Osop, Dion Hoe-Lian Goh, and Gani Kelni. 2017. "Making Sense of Comments on YouTube Educational Videos: A Self-directed Learning Perspective." Online Information Review 41 (5): 611-625. https://doi.org/10.1108/OIR-09-2016-0274.

Leung, Pamela Pui-Wan. 2017. "Learning to Engage the Digital Generation in Teacher Education." In Emerging Practices in Scholarship of Learning and Teaching in a Digital Era, edited by Siu Cheung Kong, Tak Lam Wong, Min Yang, Cheuk Fai Stephen Chow, and Ka Ho Tse, 39-54. Singapore: Springer. https://doi.org/10.1007/978-981-10-3344-5_3. 
Levin, James A., and Bertram C. Bruce. 2001. "Technology as Media: The Learner Centered Perspective." Paper presented at the American Educational Research Association, Seattle WA. https://www.ideals.illinois.edu/handle/2142/13420.

Martin, Fred G. 2012. "Will Massive Open Online Courses Change how we Teach?" Communications of the ACM 55 (8): 26-28. https://doi.org/10.1145/2240236.2240246.

Martin, Florence, Chuang Wang, Teresa Petty, Weichao Wang, and Patti Wilkins. 2018. "Middle School Students' Social Media Use." Journal of Educational Technology \& Society 21 (1): 213-224. https://www.jstor.org/stable/26273881.

Meintjes, Helgaadt, and Micheal M. van Wyk. 2020. "Facebook Page as a Digital Pedagogical Tool in the Business Studies Class." In Handbook of Research on Digital Learning edited by Matthew Montebello, 57-74. Hershey, PA: IGI Global. https://doi.org/10.4018/978-1-5225-9304-1.ch004.

Onwu, Gilbert, and Newton Stoffels. 2005. "Instructional Functions in Large, Under-resourced Science Classes: Perspectives of South African Teachers" Perspectives in Education 23 (1): 79-91. https://hdl.handle.net/10520/EJC87330.

Price, Bob. 2002. "Laddered Questions and Qualitative Data Research Interviews." Journal of Advanced Nursing 37 (3): 273-281. https://doi.org/10.1046/j.1365-2648.2002.02086.x.

Project Tomorrow. 2010. "Creating our Future: Students Speak up about their Vision for 21st Century Learning." Accessed September 10, 2019. http://www.tomorrow. org/speakup/pdfs/SU09NationalFindingsStudents\&Parents.pdf.

Ranga, Jayashree S. 2017. "Customized Videos on a YouTube Channel: A Beyond the Classroom Teaching and Learning Platform for General Chemistry Courses.” Journal of Chemical Education 94 (7): 867-872. https://doi.org/10.1021/acs.jchemed.6b00774.

Reddy, Vijay. 2005. "State of Mathematics and Science education: Schools are not Equal Conversations." Perspectives in Education $23 \quad$ (1): 125-138. https://hdl.handle.net/10520/EJC87327.

Reilly, Peter. 2012. "Understanding and Teaching Generation Y." English Teaching Forum 50 (1): 2-11. https://files.eric.ed.gov/fulltext/EJ971235.pdf.

Republic of South Africa. 2004. "White Paper on e-Education: Transforming Learning and Teaching through Information and Communication Technologies (ICTs)." Accessed April 22, 2019. https://www.gov.za/documents/e-education-draft-white-paper.

Siemens, George. 2005. "Connectivism a Theory of Learning for the Digital age." International Journal of Instructional Technology and Distance Learning 2 (1): 1-15. https://jotamac.typepad.com/jotamacs_weblog/files/Connectivism.pdf.

Snelson, Chareen, Kerry Rice, and Constance Wyzard. 2012. "Research Priorities for YouTube and Video-sharing Technologies: A Delphi Study." British Journal of Educational Technology 43 (1): 119-129. https://doi.org/10.1111/j.1467-8535.2010.01168.x.

Talbert, Joan E. 1996. "Primacy and Promise of Professional Development in the Nation's Education Reform Agenda: Sociological Views.” In Implementing Educational Reform: Sociological Perspectives on Educational Policy, edited by Peter W. Cookson, Jr., and Alan R. Sadovnik, 283-311. London: Greenwood Publishing Company.

Thorne, Kaye. 2003. Blended Learning: How to Integrate Online \& Traditional Learning. New York: Kogan Page Publishers.

Vandeyar, Saloshna, and Thirusellvan Vandeyar. 2015. The Construction, Negotiation, and Representation of Immigrant Student Identities in South African Schools. Charlotte, NC: Information Age Publishing.

Van Manen, Max. 1909. Researching Lived Experience: Human Science for an Action Sensitive Pedagogy. London: Routledge.

Waghid, Faiq. 2013. "Towards the Democratisation of Senior Phase School Science through the Application of Educational Technology." PhD diss., Stellenbosch University. http://hdl.handle.net/10019.1/85577. 
Waghid, Zayd, and Faiq Waghid. 2018. "[Re]examining the Role of Technology in Education Through a Deliberative Decision-Making Approach: In the Quest Towards Democratic Education in South African Schools." In African Democratic Citizenship Education Revisited, edited by Yusef Waghid and Nuraan Davids, 133-156. Cham: Palgrave Macmillan.

Wang, Lixun, and Qing Ma. 2017. "Community of Practice: Building a Mobile Learning Community in a Higher Education Institution to Promote Effective Teaching and Learning." In Emerging Practices in Scholarship of Learning and Teaching in a Digital Era, edited by Lixun Wang and Qing Mapp, 19-38. Singapore: Springer. https://doi.org/10.1007/978-981-10-3344-5_2.

Weinsheimer, Joel. 1995. "Shaftesbury in our Time: The Politics of Wit and Humor." Eighteenth Century 36 (2): 178-188. https://www.jstor.org/stable/41467784.

Wilson, Alison. 2015. "YouTube in the Classroom." PhD diss., University of Toronto.

Yuan, Bei, Minhong Wang, Andre W. Kushniruk, and Jun Peng. 2017. "Deep Learning towards Expertise Development in a Visualization-based Learning Environment." Journal of Educational Technology \& Society $20 \quad$ (4): $233-246$. https://www.jstor.org/stable/26229220.

\section{ABOUT THE AUTHORS}

Oscar Koopman: Senior Lecturer, SP-FET Department, Faculty of Education, Cape Peninsula University of Technology, Cape Town, South Africa

Micheal M. Van Wyk: Professor, Chair of Department, Curriculum and Instructional Studies, College of Education, University of South Africa, Pretoria, South Africa.

Karen J Koopman: Lecturer, Department of Educational Studies, Faculty of Education, University of the Western Cape, Cape Town, South Africa 
Ubiquitous Learning: An International Journal

sets out to deÿne an emerging ÿeld. Ubiquitous

learning is a new educational paradigm made possible

in part by the affordances of digital media.

Ubiquitous learning is a counterpart to the concept "ubiquitous computing," but one which seeks to put the needs and dynamics of learning ahead of the technologies that may support learning. The arrival of new technologies does not mean that learning has to change. Learning should only change for learning's sake. The key perspective of the journal is that our changing learning needs can be served by ubiquitous computing. In this spirit, the journal investigates the affordances for learning in the digital media, in school, and throughout everyday life.

Ubiquitous Learning: An International Journal is a peer-reviewed, scholarly journal. 